\title{
Energy demand analysis and energy labelling of new residential buildings in Tuscany (Italy)
}

\author{
F. Fantozzi, F. Leccese, G. Salvadori \& G. Tuoni \\ Department of Energy “L. Poggi”, Faculty of Engineering, \\ University of Pisa, Italy
}

\begin{abstract}
In this paper two low-energy-demand multi-storey residential buildings, within the Tuscany Regional Plan "20.000 Houses for Rent", are analyzed. According to the EN 15217 and to the draft of the Italian guidelines on the energy performance of buildings, the energy labelling of the two examined buildings is discussed.

Keywords: energy performance of buildings, building energy demand analysis, building energy labelling, low-energy-demand building.
\end{abstract}

\section{Introduction}

For the realization of a new building, in Italy, the prescriptions on the energy consumption reduction to be satisfied are given in the recent Legislative Decrees 192/2005 and 311/2006 [1], according to the EPBD (European Directive 2002/91/EC on energy performance of buildings). Such Decrees have introduced limit values for thermal transmittances of the building envelope components as well as limit values for the energy demand of buildings during the heating period. The evaluation of the building energy demand during the heating season has to take into account both the energy demand for space heating and that for domestic hot water (DHW) production, according to the European standards EN ISO 13790 [2], EN 12831 [3] and Italian standard UNI/TS $11300[4,5]$.

In this paper, the Authors show the results related to the energy demand evaluation of two new buildings in Tuscany (Italy) and to their energy labelling for space heating and DHW production. In the absence of a unique criterion for the energy labelling on a national level, different labelling criteria suggested by European standards and Italian local administrations are tested. By this analysis the Authors intend to show how, as for high-level-thermal-insulation buildings, the energy performance proves to be strongly influenced by the behaviour of users [6], and how the energy label can vary with the adopted labelling criterion. 


\section{Case study description}

The complex of the two studied buildings [7-9] is currently being realized in the town of Greve in Chianti (Florence, Tuscany region, Italy). The concerned plan area is situated at $236 \mathrm{~m}$ above sea level (latitude of $43^{\circ} 34^{\prime}$ North). As far as the winter heating period is concerned, the town of Greve in Chianti is characterized by 2126 degrees-day (GG) and falls into the climatic zone E. The heating period has a conventional duration of 183 day $\left(15^{\text {th }}\right.$ of October- $15^{\text {th }}$ of April).

The two buildings are composed of 4 typologies of flats, differing from each other mainly in dimensional characteristics, exposure and net area. The first is composed of 17 flats distributed on three floors. The second is composed of 8 flats distributed on three floors (see Figs. 1-3). In Figs. 1 and 2 the layout of the different typologies of flats within the two buildings can be noticed: by letter A duplex-type flats for 4 persons are indicated, by letter B single flats for 2 persons with independent entrance (external stairs), by letter $\mathrm{C}$ single flats similar to those of the type B but presenting a larger net area ( 3 persons), and, finally, by letter $\mathrm{D}$ flats similar to those of the type $\mathrm{B}$ ( 2 persons) but having a condominium entrance (on an external gallery accessible from a close stairwell with lift) are indicated.

The building envelope of both buildings is made for about $90 \%$ of opaque surfaces and, for the remaining $10 \%$ of glazed surfaces. The building, realized by a steel structure and panelling with lightened brick blocks, presents an outdoor external insulation, obtained by using expanded extruded polystyrene (mean thickness of $0.1 \mathrm{~m}$, thermal conductivity of $0.032 \mathrm{~W} / \mathrm{mK}$ ) so as to reduce as much as possible the effect of thermal bridges. With the same purpose, peculiar building solutions have been studied for the anchoring of the balconies to the bearing structure and for the realization of the pavement structure on the ground floor. Such solutions are described in detail in previous papers [7-9].

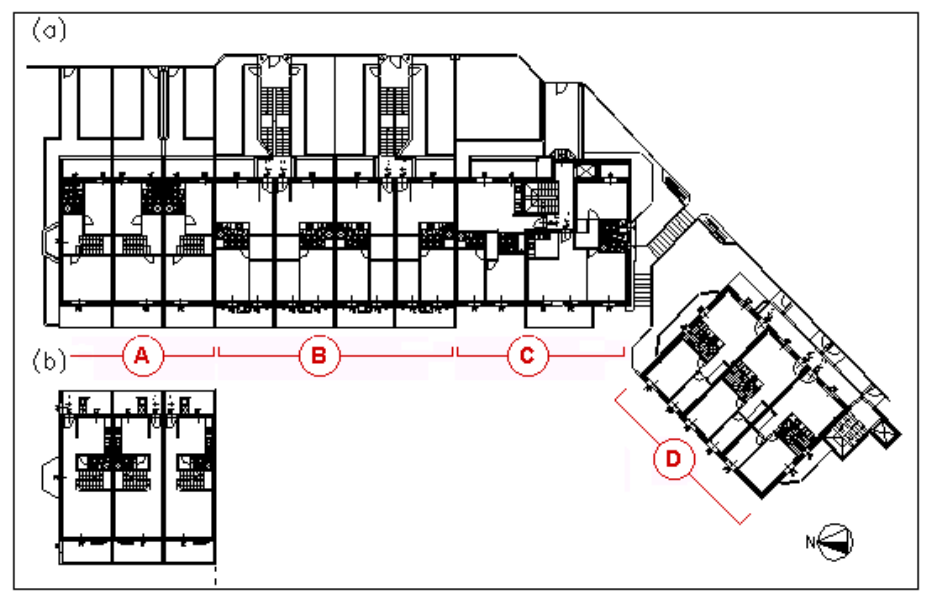

Figure 1: Design drawing of the analyzed buildings (the capital letters indicate the different typologies of flats); for the duplex flats (type A) the ground floor (a) and the first floor (b) are shown. 


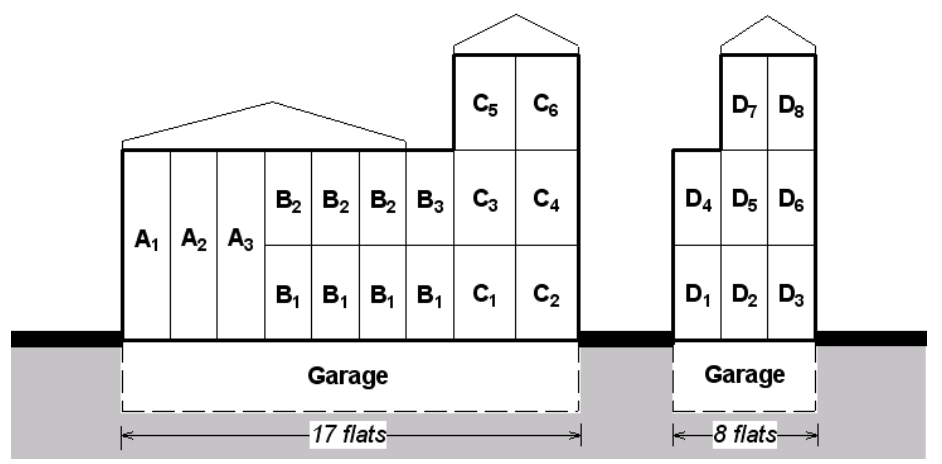

Figure 2: Schematic representation of the flats distribution.

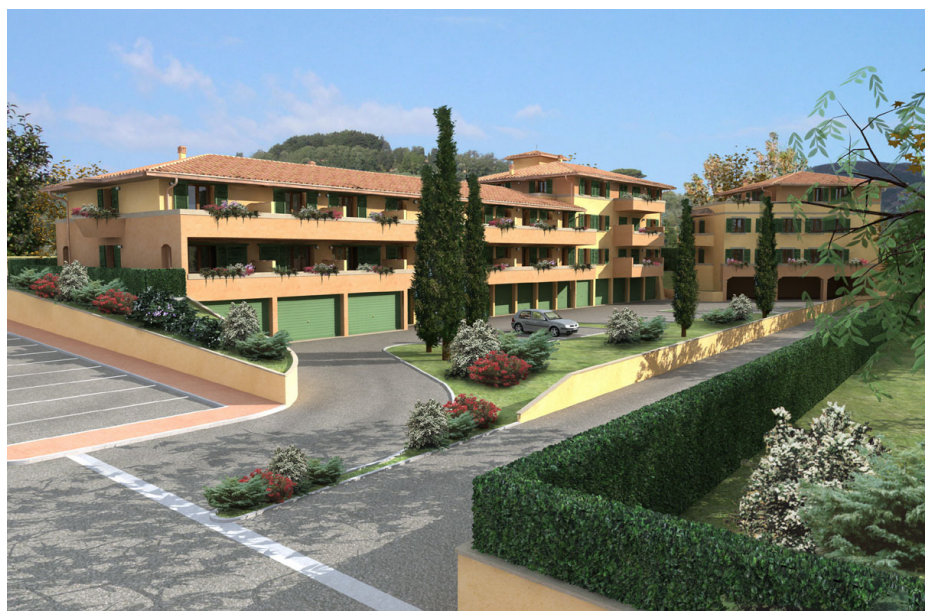

Figure 3: $\quad 3 \mathrm{D}$ view of the analyzed buildings.

In Tab. 1 the values of the thermal transmittance $U$ of the structures composing the opaque building envelope and their overall thickness $\mathrm{d}_{\mathrm{T}}$, are reported. For details on the stratigraphies of the single structures and on the techniques by which they are determined we refer to [7].

The values of thermal transmittance can be compared with respective limit values $\left(\mathrm{U}_{\text {lim }}\right)$ contemplated in [1] for the climatic zone $\mathrm{E}$ (see Tab. 1). As for the windows, they are realized with triple glass (provided with air spaces) and PVC frames allowing different opening configurations, so that the indoor natural ventilation conditions could be varied. The thermal transmittance for the chosen glass typology turns out to be $\mathrm{U}_{\mathrm{g}}=0.70 \mathrm{~W} / \mathrm{m}^{2} \mathrm{~K}\left(\left(\mathrm{U}_{\mathrm{g}}\right)_{\lim }=1.90 \mathrm{~W} / \mathrm{m}^{2} \mathrm{~K}[1]\right)$. The overall thermal transmittance of the windows, evaluated according to the EN ISO 10077-1 [10], results to be $\mathrm{U}_{\mathrm{w}}=1.30 \mathrm{~W} / \mathrm{m}^{2} \mathrm{~K}\left(\left(\mathrm{U}_{\mathrm{w}}\right)_{\mathrm{lim}}=2.40 \mathrm{~W} / \mathrm{m}^{2} \mathrm{~K}\right.$ [1]). The thermal transmittances of the opaque and glazed components turn out to be much lower than the limit values recently fixed by the Italian Regulations [1]. 
Table 1: Thermal transmittances and overall thicknesses of the enveloping opaque structures.

\begin{tabular}{|l|c|c|c|}
\hline Opaque structures & $\mathbf{d}_{\mathrm{T}}(\mathrm{m})$ & $\mathbf{U}\left(\mathrm{W} / \mathrm{m}^{2} \mathrm{~K}\right)$ & $\mathbf{U}_{\lim }\left(\mathrm{W} / \mathrm{m}^{2} \mathrm{~K}\right)$ \\
\hline External walls & 0.43 & 0.23 & 0.37 \\
\hline Ground floor & 0.51 & 0.32 & 0.38 \\
\hline Roof & 0.36 & 0.19 & 0.32 \\
\hline
\end{tabular}

\section{Energy demand analysis}

The energy analysis has been carried out on the whole complex composed of the two above-described buildings, for which the energy demand for winter heating and DHW production of each of the various flats have been evaluated.

As a significant example, the results obtained for the "duplex" flat identified by the abbreviation A1 (Figs. 1 and 2) are shown. This flat has three sides of its envelope dispersing outwards and faces north. Among the 25 investigated flats, it turns out to fall into those that show a higher energy demand for winter heating.

\subsection{Useful energy demand evaluation}

The useful energy demand evaluation for winter heating and for DHW production has been carried out according to the methods proposed in EN ISO 13790 [2], EN 12831 [3] and UNI/TS 11300 [4, 5].

The flat A1 develops on a gross area of $113 \mathrm{~m}^{2}$ (net area $92.4 \mathrm{~m}^{2}$ ) and presents the following heated gross volume: $\mathrm{V}=403 \mathrm{~m}^{3}$. The dispersing surface which contains the heated gross volume turns out to be the following: $\mathrm{S}=326 \mathrm{~m}^{2}$, and the compactness ratio $\mathrm{F}$ is: $\mathrm{F}=\mathrm{S} / \mathrm{V}=0.81 \mathrm{~m}^{-1}$. For this flat the dispersing surface turns out to consist by $92 \%$ of opaque surfaces $(55 \%$ vertical surfaces, $20 \%$ roof, $17 \%$ floors) and by $8 \%$ of glazed surfaces.

The evaluation of heat losses through the envelope has been carried out supposing the indoor air temperature $\mathrm{T}_{\mathrm{i}}=20^{\circ} \mathrm{C}$ and the outdoor air temperature $\mathrm{T}_{\mathrm{e}}=\mathrm{T}_{\mathrm{em}}$, mean monthly values indicated in the Italian standard UNI 10349 [11]. All flats are considered to be heated at the same time. The Authors have taken into account also the effects of a possible non contemporaneous turning on of the heating plants in bordering flats, evaluating the consequent energy demand in [8]. For the indoor ventilation a value of $0.3 \mathrm{~h}^{-1}$ for the air change per hour (n) has been considered. Such a value is considered to be a standard one for residential buildings and is reported in UNI/TS 11300-1 [4]. It is necessary to point out that in Italy the working-out of several regulations and prescriptions on the ventilation of residential buildings is currently being discussed. In one of these recent proposals [12] it is suggested to consider a minimum value $n=0.5 \mathrm{~h}^{-1}$ below which the indoor air hygiene and health conditions of an occupied building are neglected, while it is suggested to consider the value $n=0.8 \mathrm{~h}^{-1}$ as a reference value in case of indoor natural ventilation and airing without using controlled mechanical ventilation systems. 
(a)

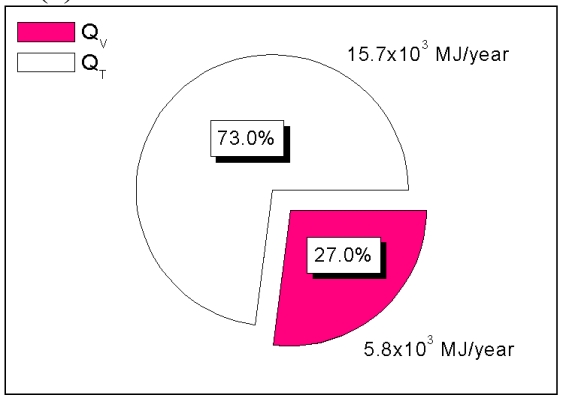

(b)

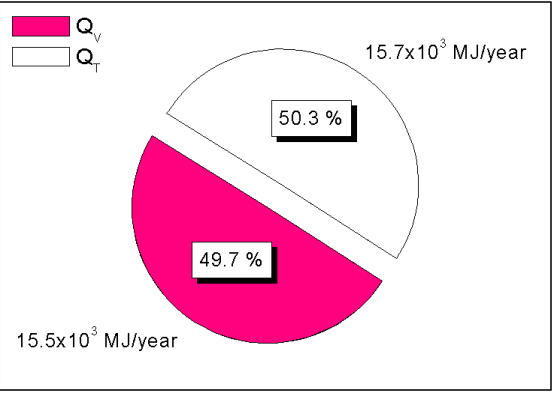

Figure 4: $\quad$ Energy demand $\mathrm{Q}_{\mathrm{T}}$ and $\mathrm{Q}_{\mathrm{V}}$ : case (a) $\mathrm{n}=0.3 \mathrm{~h}^{-1}$; case (b) $\mathrm{n}=0.8 \mathrm{~h}^{-1}$.

(a)

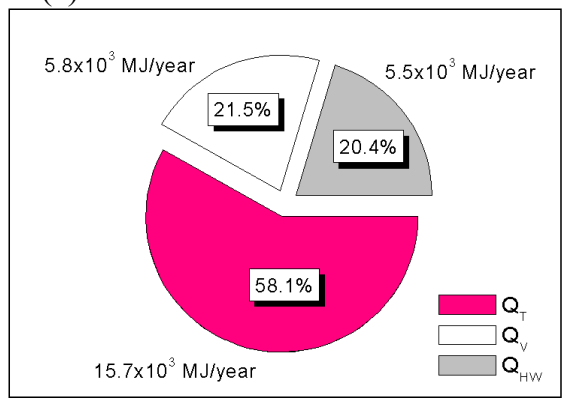

(b)

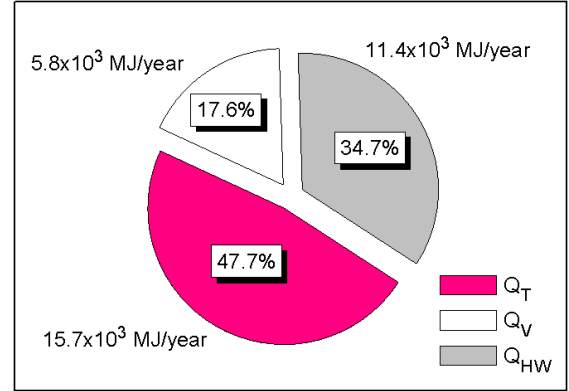

Figure 5: Comparison among the useful energy demands $\left(\mathrm{n}=0.3 \mathrm{~h}^{-1}\right)$ : case (a) $g_{\mathrm{W}}=36 \mathrm{l} /$ person day; case (b) $g_{\mathrm{w}}=75 \mathrm{l} /$ person day.

In Figs. 4(a) and (b) the energy demand values for transmission heat losses $\mathrm{Q}_{\mathrm{T}}$ and for ventilation $Q_{V}$ relating to the flat $A 1$ in the two cases $n=0.3 h^{-1}$ (Fig. 4(a)) and $n=0.8 \mathrm{~h}^{-1}$ (Fig. 4(b)) are reported. As it can be noticed from the Figs. 4(a) and (b), in high-level-thermal-insulation buildings the energy demand for ventilation turns out to be very important. As regards the analyzed flat the term $\mathrm{Q}_{\mathrm{V}}$ moves from $27 \%$ to $50 \%$, of the overall heat losses, when $\mathrm{n}$ increases from $0.3 \mathrm{~h}^{-1}$ to $0.8 \mathrm{~h}^{-1}$.

The evaluation of the yearly useful energy demand for the space heating $\mathrm{Q}_{\mathrm{H}}$ has been carried out after estimating the term due to heat gains $\mathrm{Q}_{\mathrm{G}}$ (weighed with the utilization factor $\eta_{\mathrm{G}}$ as defined in EN 12831 [3]). As regards the flat A1 the following has resulted: $\eta_{\mathrm{G}} \mathrm{Q}_{\mathrm{G}}=13.2 \cdot 10^{3} \mathrm{MJ} /$ year and $\mathrm{Q}_{\mathrm{H}}=8.4 \cdot 10^{3} \mathrm{MJ} /$ year (with: $\mathrm{Q}_{\mathrm{H}}=\mathrm{Q}_{\mathrm{T}}+\mathrm{Q}_{\mathrm{V}}-\eta_{\mathrm{G}} \mathrm{Q}_{\mathrm{G}}$ and $\mathrm{Q}_{\mathrm{V}}$ evaluated by using $\mathrm{n}=0.3 \mathrm{~h}^{-1}$ ). The estimate of the useful energy demand for the DHW production $\mathrm{Q}_{\mathrm{HW}}$ has been carried out according to the methods indicated in UNI/TS 11300-2. As for the flat A1 (4 persons and a temperature difference $\Delta \mathrm{T}$, between the cold water collected from the municipal network and the heated one, equal to $25{ }^{\circ} \mathrm{C}$ ) we obtain: DHW demand per person $\mathrm{g}_{\mathrm{W}}=36 \mathrm{l} /$ person day and $\mathrm{Q}_{\mathrm{HW}}=5.5 \cdot 10^{3} \mathrm{MJ} /$ year. As in case of ventilation of rooms, the demand for DHW production strongly depends on the behaviour of users. Think, for instance, of the variability of the parameter $g_{\mathrm{W}}$. If, 
instead of the value $g_{w}=36 \mathrm{l} /$ person day, the value $g_{w}=75 \mathrm{l} /$ person day, indicated in [13] were considered, $\mathrm{Q}_{\mathrm{HW}}=11.5 \cdot 10^{3} \mathrm{MJ} /$ year would be obtained. This choice can obviously influence the building energy labelling (see next Section).

In Figs. 5(a) and (b) the details relating to the useful energy demand for transmission through the envelope $\left(\mathrm{Q}_{\mathrm{T}}\right)$, for ventilation $\left(\mathrm{Q}_{\mathrm{V}}\right)$ with $\mathrm{n}=0.3 \mathrm{~h}^{-1}$ and for DHW production $\left(\mathrm{Q}_{\mathrm{HW}}\right)$, in the two cases $\mathrm{g}_{\mathrm{W}}=36 \mathrm{l} /$ person day (Fig. 5(a)) and $\mathrm{g}_{\mathrm{w}}=75$ 1/person day (Fig. 5(b)), are reported. In Fig. 5(a) $\mathrm{Q}_{\mathrm{T}}, \mathrm{Q}_{\mathrm{V}}$ and $\mathrm{Q}_{\mathrm{HW}}$ represent respectively, the $58.1 \%$, the $21.5 \%$ and the $20.4 \%$ of the heat losses relating to the flat A1; such losses are compensated for the $36.5 \%$ by the heat gains $\left(\eta_{\mathrm{G}} \mathrm{Q}_{\mathrm{G}}\right)$. From Figs. 5(a) and (b) it is well underlined how, in high-levelthermal-insulation buildings, the useful energy demand for DHW production results to be of remarkable importance compared to the overall energy demand.

\subsection{Primary energy demand evaluation}

The evaluation of the primary energy demand for heating and DHW production has been carried out considering each of the different flats to be provided with an autonomous plant. Such a choice turned out to be bound by specific requirements of the building firm to comply with the current expectations of the final users [7, 9]. As regards the heat generators, electronic condensation gas boilers have been considered, with minimum nominal power of $9.50 \mathrm{~kW}$ with production of DHW. As regards the emission terminals, floor radiant panels provided with modulating adjustable thermostat with pitch of $1{ }^{\circ} \mathrm{C}$ and with thermally insulated hot water inlet pipes have been considered.

The overall seasonal mean efficiency for heating and for DHW production, in relation to the considered plant, can be assumed respectively: $\eta_{\mathrm{R}}=0.80$ and $\eta_{\mathrm{W}}=0.90$. Consequently, the primary energy demand for space heating $\left(\mathrm{Q}_{\mathrm{R}}\right)$ and for DHW production $\left(\mathrm{Q}_{\mathrm{W}}\right)$ for the flat $\mathrm{A} 1$ have been evaluated respectively as: $\mathrm{Q}_{\mathrm{R}}=\mathrm{Q}_{\mathrm{H}} / \eta_{\mathrm{R}} \approx 10.5 \cdot 10^{3} \mathrm{MJ} /$ year and $\mathrm{Q}_{\mathrm{W}}=\mathrm{Q}_{\mathrm{HW}} / \eta_{\mathrm{W}} \approx 6.1 \cdot 10^{3} \mathrm{MJ} /$ year.

\section{Building energy performance indicators}

The recent Italian regulations on energy performance in building [1] introduce the indicator $\mathrm{EP}_{\mathrm{R}}$ for the energy performance evaluation as regards the heating of buildings. This indicator is defined as the ratio between the primary energy demand for the space heating $\mathrm{Q}_{\mathrm{R}}(\mathrm{kWh} / \mathrm{year})$ and the net area of the building $\left(\mathrm{m}^{2}\right)$. The value of $E P_{R}$ has to be lower than the limit value $\left(\mathrm{EP}_{\mathrm{R}}\right)_{\mathrm{L}}$ reported in [1] depending on the building compactness ratio (F) and on the degrees-day (GG). Analogously, an energy performance indicator $\mathrm{EP}_{\mathrm{W}}$ for DHW production, defined as the ratio between the primary energy demand for DHW production $\mathrm{Q}_{\mathrm{W}}$ and the net area of the building, can be introduced. National guidelines for the application of [1], in which the limit values $\left(\mathrm{EP}_{\mathrm{W}}\right)_{\mathrm{L}}$ are stated in order to assign an overall energy label of the building (see next Section), are being currently discussed. As regards the buildings analyzed in this paper, in the case relating to the reference flat $\mathrm{A} 1$, the limit value of $\left(\mathrm{EP}_{\mathrm{R}}\right)_{\mathrm{L}}$ turns out to be 81.8 $\mathrm{kWh} / \mathrm{m}^{2}$ year and the value $\mathrm{EP}_{\mathrm{R}}$ turns out to be $31.4 \mathrm{kWh} / \mathrm{m}^{2}$ year, about the $40 \%$ of the limit value fixed by the Italian regulations. For the same flat the value of 


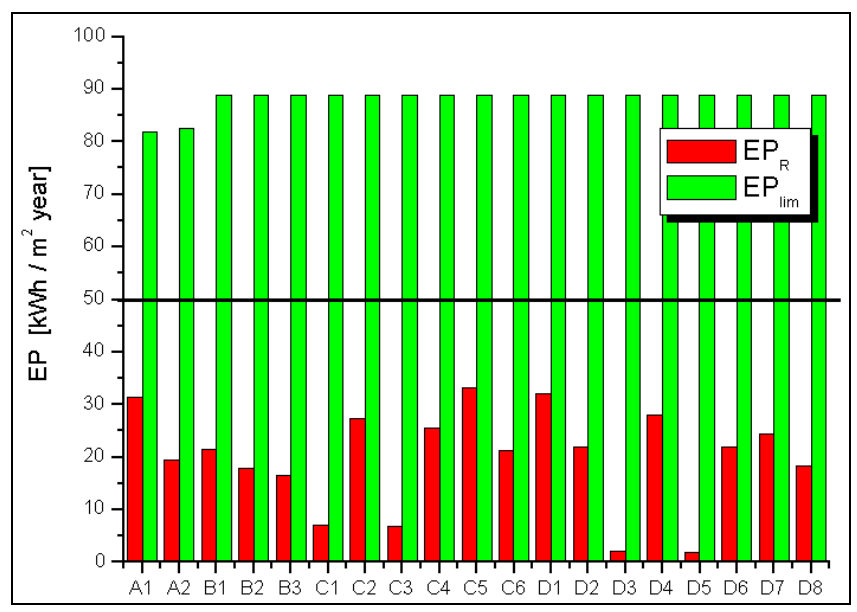

Figure 6: Values of the energy performance indicators $\mathrm{EP}_{\mathrm{R}}$ and $\left(\mathrm{EP}_{\mathrm{R}}\right)_{\mathrm{L}}$ relating to each flat.

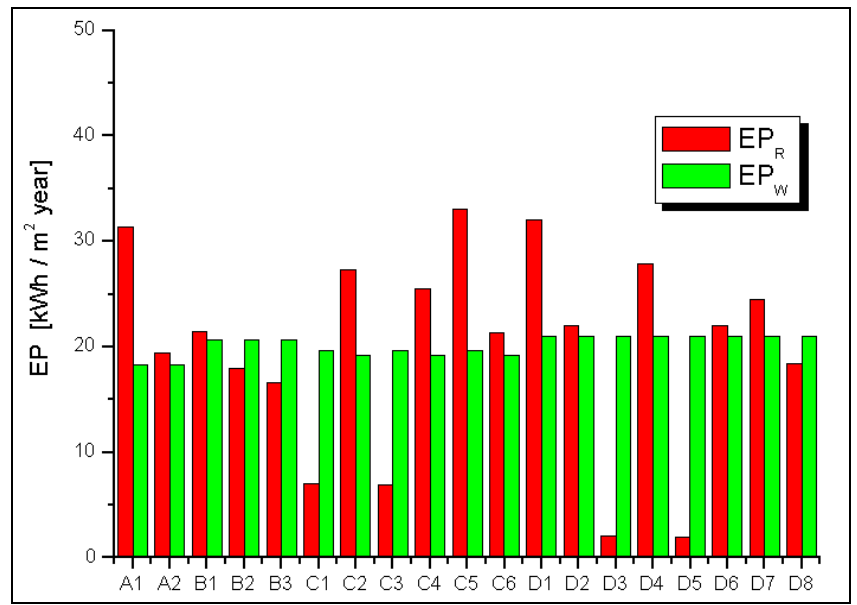

Figure 7: Values of the energy performance indicators $\mathrm{EP}_{\mathrm{R}}$ and $\mathrm{EP}_{\mathrm{W}}$ relating to each flat.

$\mathrm{EP}_{\mathrm{W}}$ turns out to be $18.3 \mathrm{kWh} / \mathrm{m}^{2}$ year. The determination of the indicators $\mathrm{EP}_{\mathrm{R}}$ and $\mathrm{EP}_{\mathrm{W}}$ has been repeated for all the flats being the subject of the energy analysis.

In Fig. 6 a comparison among the values obtained for $\mathrm{EP}_{\mathrm{R}}$ and the respective limit values $\left(\mathrm{EP}_{\mathrm{R}}\right)_{\mathrm{L}}$ is reported, while in Fig. 7 the values of $\mathrm{EP}_{\mathrm{R}}$ are compared to the $\mathrm{EP}_{\mathrm{W}}$ for each flat. The obtained results have pointed out how the indicators $\mathrm{EP}_{\mathrm{R}}$ prove to be much lower than the respective limits fixed by Italian regulations for all flats. This demonstrates the optimal energy performance of the analyzed buildings. In Fig. 6 the horizontal marked line refers to the limit of 50 $\mathrm{kWh} / \mathrm{m}^{2}$ year indicated in [14] as energy performance indicator for space heating 
below which important economical and volumetric incentives can be applied (e.g. the deduction from the building volume of the external walls thickness, up to a maximum of $0.5 \mathrm{~m}$ ). From Fig. 7 it is possible to observe how the energy performance indicators for DHW production are of the same order of magnitude (and sometimes even higher) as the indicators for space heating. Hence the importance of controlling the indicator $\mathrm{EP}_{\mathrm{W}}$ which, in case of high-level-thermalinsulation buildings can result to be a decisive element in the energy labelling of the whole building. This is the reason why in [1] has been imposed that at least the $50 \%$ of the energy demand for DHW production should be satisfied by resorting to a renewable energy source.

\section{Building energy labelling}

The energy labelling of buildings is reported in the EN 15217 [15]. Labels are marked by letters from $A$ to $G$ (according to a decreasing energy performance), as indicated in Tab. 2. In the second column of Tab. 2 by $\mathrm{R}_{\mathrm{R}}$ (Energy Performance Regulation Reference) the value according to the law being in force in the country of adoption has been indicated and by $\mathrm{R}_{\mathrm{S}}$ (Building Stock Reference) the reference value representing the average performance of the existing buildings in the country of adoption has been indicated. The third column of Tab. 2 refers to the implementation proposal of the energy labelling of buildings in Italy, recently published in the National Guidelines being currently discussed [16]. The value of $R_{S}$ will be decided on a national level and will be able to vary in time in connection with the energy performance improvement on a national level.

Currently, in Italy, in absence of regulations shared on a national level (and in consideration of the urgency to fix quality standards with as regards the energy performance of new buildings) different local energy labelling criteria have spread. At the moment regional labelling procedures, for instance, in Lombardy, Liguria and Emilia-Romagna as well as local ones in the districts of Bolzano, Trento, Vicenza, Reggio Emilia and, finally, in Tuscany, for example, in the towns of Pisa and Pontedera are already activated. In particular, such criteria can be grouped in two categories: that for which the labelling occurs considering only the energy performance indicator $\mathrm{EP}_{\mathrm{R}}$ and that contemplating, on the other hand, the use of the sum of the energy performance indicators $\mathrm{EP}^{*}=\mathrm{EP}_{\mathrm{R}}+\mathrm{EP}_{\mathrm{W}}$.

Also National Guidelines are inclined towards this latter solution [16]. For the first category the labelling criteria proposed by the Lombardy region, the town of Reggio Emilia and by the National Guidelines have been compared (see Tab. 3). The first expresses the energy labels limits with fixed and invariable values, while the others express the limits depending on the indicator $\left(\mathrm{EP}_{\mathrm{R}}\right)_{\mathrm{L}}$ indicated in [1]. For the second category the labelling criteria proposed by the Vicenza district, by the Emilia-Romagna region and by the National Guidelines have been compared (see Tab. 4). In this case the different criteria refer both to fixed and invariable limit values (e.g. Emilia-Romagna and Vicenza) and to values in part fixed and invariable for DHW production and in part expressed depending on the indicator $\left(\mathrm{EP}_{\mathrm{R}}\right)_{\mathrm{L}}$ (e.g. National Guidelines). 
Table 2: $\quad$ Proposal of energy labelling of buildings.

\begin{tabular}{|c|c|c|c|}
\hline $\begin{array}{c}\text { Energy } \\
\text { Label }\end{array}$ & EN15217 [15] & & National Guidelines [16] \\
\hline \multirow{2}{*}{ A } & \multirow{2}{*}{$E P<0.5 R_{R}$} & A+ & $E P_{R}<0.25\left(E P_{R}\right)_{L}$ \\
\hline & & $\mathbf{A}$ & $0.25\left(E P_{R}\right)_{L} \leq E P_{R}<0.5\left(E P_{R}\right)_{L}$ \\
\hline B & $0.5 R_{R} \leq E P<R_{R}$ & & $0.5\left(E P_{R}\right)_{L} \leq E P_{R}<0.75\left(E P_{R}\right)_{L}$ \\
\hline $\mathbf{C}$ & $R_{R} \leq E P<0.5\left(R_{R}+R_{S}\right)$ & & $0.75\left(E P_{R}\right)_{L} \leq E P_{R}<\left(E P_{R}\right)_{L}$ \\
\hline D & $0.5\left(R_{R}+R_{S}\right) \leq E P<R_{S}$ & & $\left(E P_{R}\right)_{L} \leq E P_{R}<1.25\left(E P_{R}\right)_{L}$ \\
\hline$E$ & $R_{S} \leq E P<1.25 R_{S}$ & & $.25\left(E P_{R}\right)_{L} \leq E P_{R}<1.75\left(E P_{R}\right)_{L}$ \\
\hline $\mathbf{F}$ & $1.25 R_{S} \leq E P<1.5 R_{S}$ & & $1.75\left(E P_{R}\right)_{L} \leq E P_{R}<2.5\left(E P_{R}\right)_{L}$ \\
\hline $\mathbf{G}$ & $\mathrm{EP} \geq 1.5 \mathrm{R}_{\mathrm{S}}$ & & $E P_{R} \geq 2.5\left(E P_{R}\right)_{L}$ \\
\hline
\end{tabular}

Table 3: Energy labelling criteria relating to energy demand for space heating only, all values are expressed in $\mathrm{kWh} / \mathrm{m}^{2}$ year.

\begin{tabular}{|c|c|c|c|}
\hline $\begin{array}{c}\text { Energy } \\
\text { Label }\end{array}$ & $\begin{array}{c}\text { Lombardy } \\
\text { region [17] }\end{array}$ & $\begin{array}{c}\text { Town of } \\
\text { Reggio Emilia [18] }\end{array}$ & $\begin{array}{c}\text { National } \\
\text { Guidelines [16] }\end{array}$ \\
\hline A+ & $E_{R_{R}}<14$ & $E P_{R}<0.15\left(E P_{R}\right)_{L}$ & $E_{R}<0.25\left(E P_{R}\right)_{L}$ \\
\hline A & $14 \leq E P_{R}<29$ & $0.15\left(E P_{R}\right)_{L} \leq E P_{R}<0.30\left(E P_{R}\right)_{L}$ & $0.25\left(E P_{R}\right)_{L}<E P_{R} \leq 0.50\left(E P_{R}\right)_{L}$ \\
\hline B & $29 \leq E P_{R}<58$ & $0.30\left(E P_{R}\right)_{L} \leq E P_{R}<0.50\left(E P_{R}\right)_{L}$ & $0.50\left(E P_{R}\right)_{L}<E P_{R} \leq 0.75\left(E P_{R}\right)_{L}$ \\
\hline C & $58 \leq E P_{R}<87$ & $0.50\left(E P_{R}\right)_{L} \leq E P_{R}<0.70\left(E P_{R}\right)_{L}$ & $0.75\left(E P_{R}\right)_{L}<E P_{R} \leq 1.00\left(E P_{R}\right)_{L}$ \\
\hline D & $87 \leq E P_{R}<116$ & $0.70\left(E P_{R}\right)_{L} \leq E P_{R}<1.00\left(E P_{R}\right)_{L}$ & $1.00\left(E P_{R}\right)_{L}<E P_{R} \leq 1.25\left(E P_{R}\right)_{L}$ \\
\hline E & $116 \leq E P_{R}<145$ & --- & $1.25\left(E P_{R}\right)_{L}<E P_{R} \leq 1.75\left(E P_{R}\right)_{L}$ \\
\hline F & $145 \leq E P_{R}<175$ & -- & $1.75\left(E P_{R}\right)_{L}<E P_{R} \leq 2.50\left(E P_{R}\right)_{L}$ \\
\hline G & $175 \leq E P_{R}$ & -- & $2.5\left(E P_{R}\right)_{L}<E P_{R}$ \\
\hline
\end{tabular}

With reference to the buildings examined in this paper, an energy labelling analysis, by using several labelling criteria valid for the climatic zone $\mathrm{E}$ $(2101<\mathrm{GG}<3000)$, has been carried out for each flat composing the two buildings. The obtained results with respect to the labelling criterion proposed in the National Guidelines, are reported in Tab. 5. From the Tab. 5 it can be observed that the energy label A can be assigned to the reference flat A1 in both cases: if the energy performance relating just to space heating is considered and if the energy performance as to space heating and DHW production are considered on the whole. In this latter case, using a DHW demand per person $\mathrm{g}_{\mathrm{w}}=75 \mathrm{l} /$ person day [13] (instead of $\mathrm{g}_{\mathrm{w}}=36 \mathrm{l} /$ person day), an energy label not higher than $\mathrm{B}$ would have been obtained. Bringing the value of $\Delta \mathrm{T}$ up to $40^{\circ} \mathrm{C}$, as suggested in [19] and leaving unchanged $\mathrm{g}_{\mathrm{W}}=36 \mathrm{l} /$ person day, an indicator $\mathrm{EP}_{\mathrm{W}}$ of $29.3 \mathrm{kWh} / \mathrm{m}^{2}$ year, allowing the attribution of the energy label $\mathrm{B}$, is also obtained.

Comparing the energy labels, obtained by using the criterion indicated in [16], to other criteria valid on a national level, significant differences can be detected. In particular, the reference flat A1 changes over from label A (National Guidelines criterion [16]) to label B (Lombardy region criterion [17]). On the contrary, using the criterion proposed by the Vicenza district [19], all the examined flats undergo a labels change towards lower energy performance 
compared to that obtained by [16], see Tab. 5. In Tab. 6 the performance indicator $\mathrm{k}=\mathrm{EP}_{\mathrm{R}} /\left(\mathrm{EP}_{\mathrm{R}}\right)_{\mathrm{L}}$, defined as one of the energy efficiency requirements for space heating in the Guidelines on Sustainable Building in Tuscany [13], is indicated. The system proposed in [13], according to the international method "Green Building Challenge" (GBC), is a score-system (based on the analysis of several requirements weighed according to qualitative criteria) contemplating a range of values included between -2 and +5 . In the new building regulations of the town of Pisa [21] an energy evaluation criterion of buildings according to the score obtained as to the indicator $\mathrm{k}$ has been adopted. For values of $\mathrm{k}$ lower than 0.50 economical incentives are contemplated (e.g. a discount on the urbanization taxes) as well as a proportional increase of the building gross area in order to stimulate the design of low-energy-consumption buildings. For values of $\mathrm{k}$ lower than 0.30 the maximum score equalling +5 for space heating is obtained.

Table 4: Energy labelling criteria relating to overall energy demand $\left(\mathrm{EP}^{*}=\mathrm{EP}_{\mathrm{R}}+\mathrm{EP}_{\mathrm{W}}\right)$, all values are expressed in $\mathrm{kWh} / \mathrm{m}^{2}$ year.

\begin{tabular}{|c|c|c|c|}
\hline $\begin{array}{c}\text { Energy } \\
\text { Label }\end{array}$ & $\begin{array}{c}\text { Vicenza } \\
\text { district }[19]\end{array}$ & $\begin{array}{c}\text { Emilia-Romagna } \\
\text { region }[20]\end{array}$ & National Guidelines [16] \\
\hline A+ & $E P^{*}<15$ & $E P^{*}<25$ & $E P^{*}<0.25\left(E P_{R}\right)_{L}+9$ \\
\hline A & $15 \leq E P^{*}<31$ & $25 \leq E P^{*}<40$ & $0.25\left(E P_{R}\right)_{L}+9<E P^{*} \leq 0.5\left(E P_{R}\right)_{L}+9$ \\
\hline B & $31 \leq E P^{*}<63$ & $40 \leq E P^{*}<60$ & $0.5\left(E P_{R}\right)_{L}+9<E P^{*} \leq 0.75\left(E P_{R}\right)_{L}+12$ \\
\hline C & $63 \leq E P^{*}<108$ & $60 \leq E P^{*}<90$ & $0.75\left(E P_{R}\right)_{L}+12<E P^{*} \leq 1.0\left(E P_{R}\right)_{L}+18$ \\
\hline D & $108 \leq E P^{*}<154$ & $90 \leq E P^{*}<130$ & $1.0\left(E P_{R}\right)_{L}+18<E P^{*} \leq 1.25\left(E P_{R}\right)_{L}+21$ \\
\hline E & $154 \leq E P^{*}<192$ & $130 \leq E P^{*}<170$ & $1.25\left(E P_{R}\right)_{L}+21<E P^{*} \leq 1.75\left(E P_{R}\right)_{L}+24$ \\
\hline F & $192 \leq E P^{*}<231$ & $170 \leq E P^{*}<210$ & $1.75\left(E P_{R}\right)_{L}+24<E P^{*} \leq 2.5\left(E P_{R}\right)_{L}+30$ \\
\hline G & $231 \leq E P^{*}$ & $210 \leq E P^{*}$ & $2.5\left(E P_{R}\right)_{L}+30<E P^{*}$ \\
\hline
\end{tabular}

Table 5: $\quad$ Energy labelling of the case study with different criteria.

\begin{tabular}{|c|c|c|}
\hline $\begin{array}{c}\text { Energy } \\
\text { labelling } \\
\text { criteria }\end{array}$ & $\begin{array}{c}\text { Energy } \\
\text { label }\end{array}$ & Flats \\
\hline \multirow{2}{*}{$\begin{array}{c}\mathrm{EP}_{\mathrm{R}} \\
\text { Ref. [16] }\end{array}$} & A+ & C1, C3, D3, D5 \\
\hline & $\mathbf{A}$ & $\mathrm{A} 1, \mathrm{~A} 2, \mathrm{~B} 1, \mathrm{~B} 2, \mathrm{~B} 3, \mathrm{C} 2, \mathrm{C} 4, \mathrm{C} 5, \mathrm{C} 6, \mathrm{D} 1, \mathrm{D} 2, \mathrm{D} 4, \mathrm{D} 6, \mathrm{D} 7, \mathrm{D} 8$ \\
\hline \multirow{3}{*}{$\begin{array}{c}\mathbf{E P}_{\mathbf{R}} \\
\text { Ref. [17] }\end{array}$} & A+ & C1, C3, D3, D5 \\
\hline & A & A2, B1, B2, B3, C2, C5, D1, D2, D4, D6, D7, D8 \\
\hline & B & A1, C5, D1 \\
\hline \multirow{2}{*}{$\begin{array}{c}E P_{w} \\
\text { Ref. [16] }\end{array}$} & $\mathbf{F}$ & $\mathrm{B} 1, \mathrm{~B} 2, \mathrm{~B} 3, \mathrm{C} 2, \mathrm{C} 4, \mathrm{C} 6, \mathrm{D} 1, \mathrm{D} 2, \mathrm{D} 3, \mathrm{D} 4, \mathrm{D} 5, \mathrm{D} 6, \mathrm{D} 7, \mathrm{D} 8$ \\
\hline & $\mathbf{G}$ & $\mathrm{A} 1, \mathrm{~A} 2, \mathrm{C} 1, \mathrm{C} 3, \mathrm{C} 5$ \\
\hline \multirow{2}{*}{$\begin{array}{c}\text { EP }^{*} \\
\text { Ref. [16] }\end{array}$} & A+ & C1, C3, D3, D5 \\
\hline & A & $\mathrm{A} 1, \mathrm{~A} 2, \mathrm{~B} 1, \mathrm{~B} 2, \mathrm{~B} 3, \mathrm{C} 2, \mathrm{C} 4, \mathrm{C} 5, \mathrm{C} 6, \mathrm{D} 1, \mathrm{D} 2, \mathrm{D} 4, \mathrm{D} 6, \mathrm{D} 7, \mathrm{D} 8$ \\
\hline \multirow{2}{*}{$\begin{array}{c}\text { EP }^{*} \\
\text { Ref. [19] }\end{array}$} & A & C1, C3, D3, D5 \\
\hline & B & $\mathrm{A} 1, \mathrm{~A} 2, \mathrm{~B} 1, \mathrm{~B} 2, \mathrm{~B} 3, \mathrm{C} 2, \mathrm{C} 4, \mathrm{C} 5, \mathrm{C} 6, \mathrm{D} 1, \mathrm{D} 2, \mathrm{D} 4, \mathrm{D} 6, \mathrm{D} 7, \mathrm{D} 8$ \\
\hline
\end{tabular}


Table 6: $\quad$ Energy performance indicator, k, of the case study.

\begin{tabular}{|c|l|}
\hline $\mathbf{k}$ & Flats \\
\hline 0.4 & $\mathrm{~A} 1, \mathrm{C} 5, \mathrm{D} 1$ \\
\hline 0.3 & $\mathrm{C} 2, \mathrm{C} 4, \mathrm{D} 4, \mathrm{D} 7$ \\
\hline 0.2 & $\mathrm{~A} 2, \mathrm{~B} 1, \mathrm{~B} 2, \mathrm{~B} 3, \mathrm{C} 6, \mathrm{D} 2, \mathrm{D} 6, \mathrm{D} 8$ \\
\hline 0.1 & $\mathrm{C} 1, \mathrm{C} 3$ \\
\hline 0.02 & $\mathrm{D} 3, \mathrm{D} 5$ \\
\hline
\end{tabular}

\section{Conclusive remarks}

According to the results obtained, the investigated buildings can be considered "low energy consumption buildings". The examined flats show, in fact, energy performance indicators as for winter heating included in the range $2 \div 33 \mathrm{kWh} / \mathrm{m}^{2}$ year, much lower than the respective limit values fixed by Italian regulations. The energy labels have been assigned to each of the flats according to different criteria currently used in Italy. Among the labelling criteria considered in this paper, a non-homogeneity can be pointed out both in the labelling criteria and in the limit values indicated for each label. Such non-homogeneities can lead to the attribution of different energy labels for the same building depending on the criterion adopted.

In well-insulated buildings, the energy demand for ventilation and DHW production represent a significant share of the overall winter building energy demand. This share varies with the behaviour of users. However, supposing a standardized behaviour, complying with the most recent regulations being in force in Italy, it can be estimated around the $40 \%$.

The energy demand for summer air-conditioning is not considered in any of the analyzed methods, despite the fact that the European Directive 2002/91/CE makes explicit reference to the importance of controlling such an energy demand. The energy labelling method for buildings, as well as the introduction into the calculation procedures of performance indicators relating to summer airconditioning, should be, then, standardized on a national level in a short time.

\section{References}

[1] Decreto Legislativo 19/08/2005 n.192, Attuazione della direttiva 2002/91/CE relativa al rendimento energetico nell'edilizia (modified by D. Lgs. 29/12/2006 n.311), in Italian (http://www.camera.it/parlam/leggi/ deleghe/testi/06311dl.htm).

[2] EN ISO 13790, Energy performance of buildings - Calculation of energy use for space heating and cooling (in Italy UNI EN ISO, June 2008).

[3] EN 12831, Heating systems in buildings - Method for calculation of the design heat load (in Italy UNI EN 12831, December 2006).

[4] UNI/TS 11300-1, Prestazioni energetiche degli edifici-Climatizzazione e preparazione acqua calda per usi igienico-sanitari - Parte 1: Fabbisogno di energia termica dell'edificio per la climatizzazione estiva ed invernale, May 2008, in Italian. 
[5] UNI/TS 11300-2, Prestazioni energetiche degli edifici-Climatizzazione e preparazione acqua calda per usi igienico-sanitari - Parte 2: Energia primaria e rendimenti per la climatizzazione invernale e per la produzione di acqua calda per usi igienico sanitari, May 2008, in Italian.

[6] Leccese F., Salvadori G., Tuoni G., D’Acunto P., Architectural design and energy analysis of a complex of residential buildings in Paris. PLEA $2008-$ Proc. of the $25^{\text {th }}$ PLEA Int. Conf. <Towards Zero Energy Building >, Dublin (IRL), 2008, CD-Rom, ISBN: 78-1-905254-34-7, pp. 1-6.

[7] Fantozzi F., Leccese F., Salvadori G., Cappelli A., Pacenti A., Energy performance of buildings and local energy policy: the case of new residential buildings in Greve in Chianti. CISBAT 2007 - Proc. of the Int. Conf. <Renewables in a changing climate - Innovation in the built environment $>$, Lausanne (CH), September 2007, CD-Rom, pp. 109-114, 2007.

[8] Fantozzi F., Leccese F., Salvadori G., Tuoni G., Space heating and domestic hot water energy demand in high-level-insulation multistorey buildings. CISBAT 2007 - Proc. of the Int. Conf. <Renewables in a changing climate - Innovation in the built environment $>$, Lausanne $(\mathrm{CH})$, September 2007, CD-Rom, pp. 115-120, 2007.

[9] Tuoni G., Ciampi M., Fantozzi F., Leccese F., Edifici a basso consumo energetico, casi studio: case unifamiliari in legno ed edifici multipiano per appartamenti, in <Certificazione energetica e verifica ambientale degli edifici>, Flaccovio, Palermo (I), 2007, pp. 195-210, in Italian.

[10] EN ISO 10077-1, Thermal performance of windows, doors and shutterCalculation of thermal transmittance - General (in Italy UNI EN ISO 10077-1, March 2007).

[11] UNI 10349, Riscaldamento e raffrescamento degli edifici - Dati climatici, April 1994, in Italian.

[12] Raisa V., Zecchin R., Xavier B., La ventilazione negli edifici residenziali. CDA-Condizionamento dell'Aria, Riscaldamento, Refrigerazione, 2008, n. 2, pp. 20-26, in Italian.

[13] Regione Toscana, Linee guida per l'edilizia sostenibile in Toscana. Giunta Regionale, Delibera 3 April 2006 n. 218, in Italian (http://www.rete.toscana.it).

[14] Greve in Chianti (2005). Regolamento Edilizio Comunale, in Italian (http://www.comune.greve-in-chianti.fi.it).

[15] EN 15217, Ventilation for buildings - Calculation methods for the determination of air flow rates in buildings including infiltration (in Italy UNI EN 15242, February 2008).

[16] Doniselli A. (2008). Certificazione energetica degli edifici, commenti alle bozze delle linee guida nazionali. neo-Eubios, n. 23, pp. 51-61, in Italian.

[17] Regione Lombardia, Certificazione energetica degli edifici-Modifiche ed integrazioni alla Delibera della Giunta Regionale 5018/2007. Giunta Regionale, Delibera 31/12/2007 n. 8/5773, in Italian (http://www.infopoint.it/burlnew/home/home.aspx). 
[18] Comune di Reggio Emilia (Assessorato Urbanistica ed Edilizia), Regolamento edilizio comunale, 2006, in Italian (http://www.municipio.re.it).

[19] Provincia di Vicenza (Direzione e Coordinamento), Progetto EcoDomus.vi - Classificazione energetica degli edifici, 2008, in Italian (http://www.vienergia.it).

[20] Regione Emilia-Romagna, Atto di indirizzo e coordinamento sui requisiti di rendimento energetico e sulle procedure di certificazione energetica degli edifici. Assemblea Legislativa, Delibera 4 March 2008 n. 156, in Italian.

[21] Comune di Pisa (Assessorato Ambiente, Assessorato Urbanistica ed Edilizia Privata), Regolamento Edilizio - Norme per l'edilizia sostenibile (revisione Gennaio 2009), in Italian. 